\title{
Growth and yield promoting effect of artificial mycorrhization combined with different fertiliser rates on field-grown tomato
}

\author{
Vincenzo Candido, ${ }^{1}$ Gabriele Campanelli, ${ }^{2}$ Trifone D'Addabbo, ${ }^{3}$ Donato Castronuovo, ${ }^{1}$ \\ Marek Renco, ${ }^{4}$ Ippolito Camele ${ }^{1}$
}

${ }^{1}$ School of Agricultural, Forest, Food and Environmental Sciences, University of Basilicata, Potenza, Italy; ${ }^{2}$ Agricultural Research Council, Research Unit for Vegetable Crops in Central Areas (CRAORA), Monsampolo del Tronto (AP), Italy; ${ }^{3}$ Institute for Plant Protection (IPP), National Research Council, Bari, Italy; ${ }^{4}$ Parasitological Institute, Slovak Academy of Sciences, Kosice, Slovak Republic

\begin{abstract}
Combination of plant inoculation with a commercial mycorrhizal formulation with half or full fertiliser application rates was evaluated for the effects on plant growth and yield and mycorrhization occurrence throughout two consecutive field tomato crops in southern Italy. Mycorrhizal formulation was inoculated on tomato seedling roots both in the nursery and after transplant. Inoculated tomato seedlings were significantly larger than non-inoculated seedlings less than 30 days after the first inoculation in the nursery. Above ground dry biomass and stem number of inoculated plants were found to be higher also at the end of each crop. Positive effects of mycorrhizal inoculation were extended also to marketable yield of both crops, mainly due to an increased number and weight of clusters and fruits. Mycorrhizal treatment also improved crop earliness, seen in terms of anticipating plant
\end{abstract}

Correspondence: Trifone D'Addabbo, Institute for Plant Protection (IPP), National Research Council, via G. Amendola 122/D, 70126 Bari, Italy. Tel. +39.0971.205371 - Fax: +39.0971.205378.

E-mail: t.daddabbo@ba.ipp.cnr.it

Key words: arbuscular mycorrhizal fungi, fertilisers, yield, mycorrhizal, plant-growth-promoting rhizobacteria, tomato.

Contributions: the authors contributed equally.

Funding: this work was supported by the Italian Ministry of Agricultural and Forestry Policies (MIPAF), research project PROM (Progetto di Ricerca per potenziare la competitività di Orticole in aree Meridionali - funds C.I.P.E., Resolution 17/2003, Scientific Co-ordinator: Dr. Agostino Falavigna).

Acknowledgements: the authors thank Paolo Putignano and Cosimo Danzi for their valuable help in conducting the experimental trials.

Received for publication: 11 May 2013.

Revision received: 4 July 2013.

Accepted for publication: 8 July 2013.

(C) Copyright V. Candido et al., 2013

Licensee PAGEPress, Italy

Italian Journal of Agronomy 2013; 8:e22

doi:10.4081/ija.2013.e22

This article is distributed under the terms of the Creative Commons Attribution Noncommercial License (by-nc 3.0) which permits any noncommercial use, distribution, and reproduction in any medium, provided the original author(s) and source are credited. flowering, increasing first harvest yield, and reducing average harvesting time compared to non-inoculated plants. Both rates of mineral fertilisers positively affected tomato growth and marketable yield, but did not influence fruit quality parameters. No significant interaction was found between mineral fertilisation and plant mycorrhization. Crop inoculation with mycorrhizal formulations could reduce the amounts of fertilisers and pesticides being used, and could represent a sustainable technique to improve crop yield and profitability.

\section{Introduction}

Microbial activity in the rhizosphere is a primary determinant of plant health and soil fertility (Jeffries et al., 2003). Among mycorrhizal fungi symbiotically associated to plant roots, arbuscular mycorrhizal fungi (AMF) are the most important for agriculture, and are extremely beneficial to host plants (Gosling et al., 2006). Benefits of AMF are mainly related to an improved uptake of relatively immobile phosphate ions, although an increased uptake of macronutrients other than phosphorous (P), including nitrogen, potassium and magnesium, has also been observed (Smith and Read, 2008; Hodge et al., 2001). Increased plant resistance to insects and soil pathogens, and tolerance of salinity, heavy metals and drought, were also reported as further AMF benefits to the host plant (Allen, 2009; Avis et al., 2008; Brundrett, 2009; van der Heijden et al., 1998).

Plant-growth-promoting rhizobacteria (PGPR) and plant-growthpromoting fungi are further components of rhizosphere microflora that can also play a relevant role in plant growth and phytopathogen suppression, mainly due to their synergistic interaction with mychorrhizae (Compant et al., 2005; Jeffries et al., 2003).

Synergistic positive interactions between AMF and PGPR, such as nitrogen fixers, fluorescent Pseudomonads and sporulating bacilli, have been documented by many researchers (Galleguillos et al., 2000; Hameeda et al., 2007), although some neutral effects of AMF-PGPR interaction have also been reported (Andrade et al., 1997; Walley and Germida, 1997).

Massive application of pesticides and fertilisers, as well as close rotations and deep tillage, resulted in a gradual depletion of soil fertility and microbial diversity in intensive agricultural systems (Daniell et al., 2001; Tilman et al., 2002). Conventionally managed soils were found to exhibit a poorer microflora and a lower biological activity than less intensively or organically managed soils (Mäder et al., 2002). Breeding programmes have also aimed to select high chemical inputs, almost completely ignoring the interactions between plant roots and rhizosphere microorganisms (Wissuwa et al., 2009).

Artificial plant inoculation with appropriate formulations of AMF 
and PGPR can improve plant adsorption of water and nutrients with a reduction in the use of chemical fertilisers and pesticides resulting in higher crop sustainability. Beneficial effects of AMF inoculation on plant growth and yield were widely documented for vegetable crops (Douds et al., 2007; Hamel and Plenchette, 2007; Larsen et al., 2007). Technical issues raised by the large amount of inoculum needed for AMF application in the field can be effectively avoided by mycorrhizal inoculation of seedlings or cutting beds over a much smaller surface (Jeffries et al., 2003). An improvement in crop productivity following artificial inoculation with AMF formulations has been documented also for tomato, as a consequence of plant phenological, molecular and metabolic variations and systemic effects on fruits (Conversa et al., 2012; Salvioli et al., 2012).

In intensive vegetable cropping systems, potential benefits of mychorrhizal inoculation may be compromised by the massive input of mineral fertilisers. A reduced AMF colonisation of roots and spore density in soil was generally reported, mainly in the presence of an intensive use of P fertilisers (Kahiluoto et al., 2001; Kogelmann et al., 2004), although a negative impact on AMF colonisation and/or diversity has often been documented also for other readily soluble fertilisers, particularly nitrogen $(\mathrm{N})$ fertilisers (Burrows and Pfleger, 2002; Treseder and Allen, 2002).

This paper reports the results of a field experiment in southern Italy aimed at investigating the agronomical effects of tomato inoculation with a commercial AMF and PGPR formulation, and its interactions with different levels of mineral fertilisers throughout two consecutive crops.

\section{Materials and methods}

The experiment was carried out during 2006-2007 in a field on the experimental farm Pantanello at Metaponto, in the Province of Matera, southern Italy $\left(40^{\circ} 24^{\prime} \mathrm{N} ; 16^{\circ} 48^{\prime} \mathrm{E} ; 10 \mathrm{~m}\right.$ asl).

Field soil was sandy-loamy (51.3\% loam, $29.0 \%$ sand, $19.7 \%$ clay), with a $7.7 \mathrm{pH}, 0.8 \mathrm{~g} / \mathrm{kg}$ total nitrogen, and 21.2 and $215 \mathrm{mg} / \mathrm{kg}$ exchangeable phosphorous and potassium, respectively.

Soil was $30-\mathrm{cm}$ ploughed, rotavated and levelled, and the field was subdivided into nine $27 \mathrm{~m}^{2}$ plots. At ploughing, 80,100 and $200 \mathrm{~kg} \mathrm{ha}^{-1}$ of $\mathrm{N}, \mathrm{P}_{2} \mathrm{O}_{5}$ and $\mathrm{K}_{2} \mathrm{O}$ fertilisers, respectively, were applied to three plots; another three plots received half the quantity of the same fertilisers, and the remaining three plots did not receive any fertiliser at all.

For both years, cherry tomato $\mathrm{HF}_{1}$ PX 02325715 (Seminis srl, Parma, Italy) was sown broadcast in a turf-based substrate $(60 \%$ organic matter, $6.0-6.5 \mathrm{pH}$ ) in a $62 \times 35 \mathrm{~cm}$ box. At full extension of cotyledon leaves, bare root seedlings were transferred singly to 60 -cell polystyrene sowing trays, $63 \mathrm{~mL}$ of the same substrate in each cell. Half seedlings from each tray were inoculated with $1.15 \mathrm{~mL} /$ cell of a commercial microbial formulation (Micosat F, CCS AOSTA Srl, Aosta, Italy), containing ground mycorrhizal roots, spores and mycelia of AMF Glomus mosseae GP11, G. viscosum GC41, G. intraradices GB67, as well as PGPR as Pseudomonas sp. PN 01, P. fluorescens PA28, Bacillus subtilis BA41, Streptomyces sp. SB14, and the antagonistic saprophytic fungus Trichoderma viride TH03.

Forty-day old seedlings were transplanted in the field on $15^{\text {th }}$ May

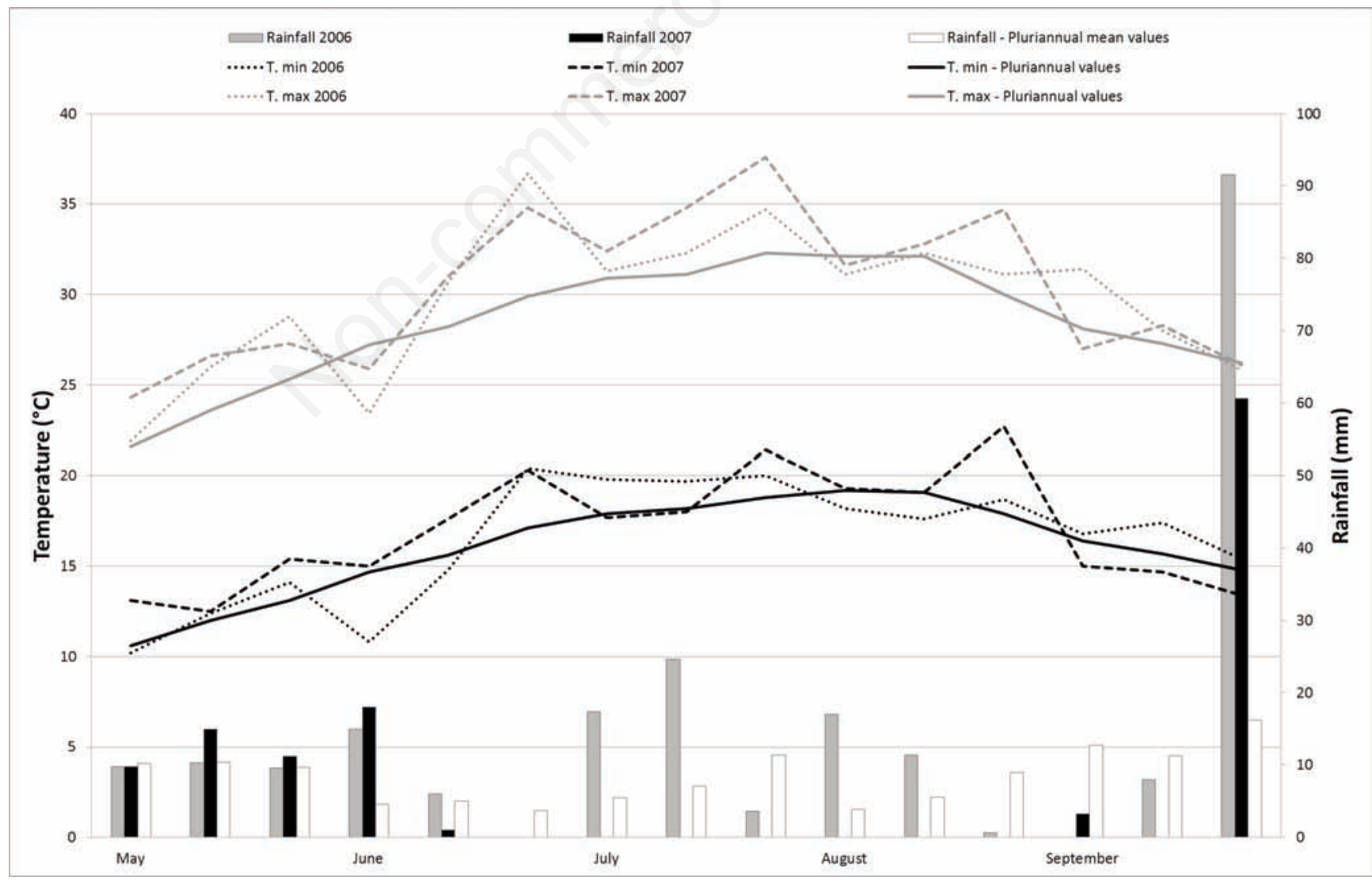

Figure 1. Ten-day minimum and maximum temperature and rainfall trends recorded during the two tomato crop cycles and compared to the pluriannual values. 
2006 and $25^{\text {th }}$ May 2007. Each plot was subdivided into two $13.5 \mathrm{~m}^{2}$ subplots, and each transplanted with inoculated or non-inoculated seedlings. Plants were spaced $30 \mathrm{~cm}$ apart within double rows, $1.5 \mathrm{~m}$ between each row. A further $1.15 \mathrm{~mL}$ of the microbial formulate were poured in the soil beside each previously inoculated seedling so as to reach a total $100 \mathrm{~L} \mathrm{ha}^{-1}$ application rate. Therefore, the experiment was arranged in a split plot randomised design, with three replicates of five different treatments and non-treated soil as control.

Top-dress 60 and $30 \mathrm{~kg} \mathrm{ha}^{-1} \mathrm{~N}$, split into three applications from plant rooting to flowering, were provided to the plots with full and half basal fertilisation, respectively. Plant irrigation was provided throughout both crops by a drip irrigation system: dripper lines $0.5 \mathrm{~m}$ apart and emitters (2.5 $\mathrm{L} \mathrm{h}^{-1}$ water flow rate) spaced $0.20 \mathrm{~m}$ from each other. Non-systemic chemical treatments were applied, as needed, for weed and insect pest control.

Daily maximum and minimum air temperatures and rainfall were recorded by a CR-10X data-logger (Campbell Scientific, Inc., Logan, UT, USA).

Dates of initiation of different plant phenological phases were recorded throughout each crop.

At transplant of each crop, stem height and diameter, above ground and root dry weight, and leaf area (Area Meter LI-Cor, Inc., Lincoln, NE, USA; Model 3100) were recorded on 10 inoculated and non-inoculated seedlings. At half crop cycle and before fruit setting, plant height and number of stems, above ground dry biomass and leaf area index (LAI) were recorded on three plants from each plot.

Tomato fruits were harvested on $28^{\text {th }}$ July, $10^{\text {th }}$ August and $4^{\text {th }}$ September 2006, and on $10^{\text {th }}$ and $31^{\text {st }}$ August 2007 in the first and second cycle, respectively. At each harvest, tomato yield of each plot was estimated by recording number and weight of ripe clusters from 20 plants. Number and weight of marketable and waste fruits were recorded on 10 clusters from each plot. Average fruit weight, soluble solid ( ${ }^{\circ}$ Brix) and dry matter content were recorded on 10 marketable fruits from each plot.

Percentage incidence of first harvest yield on total cumulative yield and mean harvesting time (MHT) were calculated as indicators of crop earliness. MHT was calculated according to the following formula:

$$
\operatorname{TMR}(\mathrm{dd})=\sum\left(y_{1^{*}} d_{1}\right) \ldots \ldots\left(y_{n} * d_{n}\right) / Y
$$

where:

$d$ is days between crop transplant and harvest beginning;

$y$ is yield at each harvest;

$Y$ is total cumulative marketable yield.

At end of harvest, we counted number of stems per plant and above ground dry biomass weight was recorded as the cumulative dry weight of oven-dried stem, leaves and fruits of plants from each sampling area. Harvest index was calculated as a ratio between fruits and total dry matter weight. Mycorrhizal root colonisation was estimated on $302-\mathrm{cm}$ fragments randomly taken from each root sample of inoculated plants after clearing and staining (Brundrett et al., 1984). Frequency of colonisation (F), intensity of colonisation ( $\mathrm{m} \%$ ), and presence of arbuscules and vesicles ( $\mathrm{a} \%$ ) were determined according to Trouvelot et al. (1986) using Mycocalc software (INRA, Dijon, France).

All data were statistically analysed by ANOVA and means separated by the Student-Newman-Keuls (SNK) test.

\section{Results}

\section{Climatic trend}

Maximum air temperatures averaged $36.7^{\circ} \mathrm{C}$ during the last ten days of June 2006 , and $34.8^{\circ} \mathrm{C}$ and $34.3^{\circ} \mathrm{C}$ in the second ten days of July and the third ten days of August 2007, respectively (Figure 1). In both years, mean maximum temperatures remained over $30^{\circ} \mathrm{C}$ from the second ten days of June to the last ten days of August, exceeding $40^{\circ} \mathrm{C}$ on June $20^{\text {th }}$ and August $20^{\text {th }} 2006$, and on June $2^{\text {nd }}$ and $26^{\text {th }}$ and July $24^{\text {th }} 2007$. Average minimum temperatures peaked at $20.4^{\circ} \mathrm{C}$ and $22.2^{\circ} \mathrm{C}$ in the last ten days of June 2006 and the last ten days of August 2007.

From May to August 2006, rainfall was concentrated in the first ten days of June $(15 \mathrm{~mm})$, in the first $(17.4 \mathrm{~mm})$ and second $(24.6 \mathrm{~mm})$ ten days of July, and in the first $(14.6 \mathrm{~mm})$ and second $(13.8 \mathrm{~mm})$ ten days of August. Rainfall was lower and less frequent in 2007; rain fell mainly in May $(9.8 \mathrm{~mm}, 15 \mathrm{~mm}$ and $11.2 \mathrm{~mm}$ in the first, second and third ten days, respectively) and June (18 $\mathrm{mm}$ in the first ten days). There was no rain at all during May 2006 or from $13^{\text {th }}$ June to $24^{\text {th }}$ September 2007.

\section{Plant growth parameters}

At transplant, almost all tomato seedling growth parameters were affected by the previous mycorrhizal inoculation in the nursery (Table 1). Height, above ground and root dry weight and dry matter content of inoculated seedlings were higher than those of non-inoculated plants. Inoculated seedlings also showed a wider leaf area and a higher number of leaves per plant.

At half crop cycle, plant height, top dry weight and leaf area index were significantly higher in the second than in the first crop (Table 2). In contrast, a larger number of plant branches and a delayed flowering,

Table 1. Effects of mycorrhization on morphological traits of tomato seedlings at transplant.

\begin{tabular}{|c|c|c|c|c|c|c|c|c|c|}
\hline \multirow[t]{2}{*}{ Year } & \multirow{2}{*}{$\begin{array}{l}\text { Mycorrhizal } \\
\text { treatment }\end{array}$} & \multicolumn{2}{|c|}{ Stems } & \multicolumn{2}{|c|}{ Leaves/plant } & \multicolumn{2}{|c|}{ Epigeal part } & \multicolumn{2}{|c|}{ Roots } \\
\hline & & $\begin{array}{l}\text { Height } \\
\text { (cm) }\end{array}$ & $\begin{array}{l}\text { Thickness } \\
\text { (mm) }\end{array}$ & Number & $\begin{array}{l}\text { Area } \\
\left(\mathrm{cm}^{2}\right)\end{array}$ & $\begin{array}{l}\text { Dry weight/ } \\
\text { plant } \\
\text { (mg) }\end{array}$ & $\begin{array}{l}\text { Dry } \\
\text { matter } \\
(\%)\end{array}$ & $\begin{array}{c}\text { Dry weight/ } \\
\text { plant } \\
\text { (mg) }\end{array}$ & $\begin{array}{l}\text { Root/shoot dry } \\
\text { weight ratio }\end{array}$ \\
\hline \multirow[t]{3}{*}{2006} & Micosat F. & $12.2^{\mathrm{a}}$ & $3.3^{\mathrm{a}}$ & $5.7^{\mathrm{a}}$ & $31.0^{\mathrm{a}}$ & $249^{a}$ & $9.8^{\mathrm{a}}$ & $103^{\mathrm{a}}$ & $2.6^{\mathrm{a}}$ \\
\hline & Control & $9.5^{b}$ & $3.0^{\mathrm{b}}$ & $4.7^{\mathrm{b}}$ & $12.4^{\mathrm{b}}$ & $90^{\mathrm{b}}$ & $8.8^{b}$ & $42^{\mathrm{b}}$ & $2.2^{b}$ \\
\hline & Significance & $* *$ & $*$ & $* *$ & $* *$ & $* *$ & $* *$ & $* *$ & $*$ \\
\hline \multirow[t]{3}{*}{2007} & Micosat F. & $21.0^{\mathrm{a}}$ & $2.9^{\mathrm{a}}$ & $6.0^{\mathrm{a}}$ & $76.4^{\mathrm{a}}$ & $365^{\mathrm{a}}$ & $9.6^{\mathrm{a}}$ & $115^{\mathrm{a}}$ & $3.2^{\mathrm{a}}$ \\
\hline & Control & $17.4^{\mathrm{b}}$ & $2.9^{\mathrm{a}}$ & $5.3^{b}$ & $66.9^{b}$ & $318^{b}$ & $9.8^{\mathrm{a}}$ & $102^{b}$ & $3.0^{\mathrm{b}}$ \\
\hline & Significance & $* *$ & ns & $* *$ & $* *$ & $* *$ & ns & $* *$ & $*$ \\
\hline
\end{tabular}

a,beans followed by the same letters in the same column and within each experiment are not significantly ( $\alpha \leq 0.05)$ different according to the Student-Newman-Keuls Test. *P $\leq 0.05$ was considered significant; **P $\leq 0.01$. ns, non-significant. 
fruit setting and veraison occurred in the first tomato crop.

Mineral fertilisation positively affected plant growth; height, above ground dry biomass, leaf area index and stem number of plants from both full and half fertilised plots were significantly higher than in nonfertilised soil, although the increase in growth was much more evident in plots receiving the full quantity of fertiliser. Compared to non-fertilised plots, mineral fertilisation also resulted in a significantly earlier flowering and fruit veraison, whereas no significant differences were found between the two quantities of fertiliser. Plants inoculated with the mycorrhizal formulation were significantly taller, and had higher above ground dry biomass and LAI, and a significantly earlier flowering and veraison than non-inoculated plants.

Final above ground dry biomass was significantly higher in the second than in the first crop (Table 3). Compared to non-fertilised control, half and full rate mineral fertilisation increased final above ground dry biomass by 2.7 and $4.2 \mathrm{t} \mathrm{ha}^{-1}$, respectively, and number of stems per plant by 2 units. Plant inoculation with the mycorrhizal formulation also resulted in a significant increase in above ground dry biomass and number of stems per plant: $+0.6 \mathrm{tha}^{-1}$ and +1.1 units, respectively.

\section{Yield parameters}

Tomato yield was significantly higher in the second than in the first crop due to a lower number of clusters and fruits per plant, and to a lower fruit dry matter and soluble solid contents (Table 3). A longer length cycle and a 2-week delay in fruit ripening and harvest were also observed in the first crop.

Marketable yield was always significantly higher in soil receiving both half and full fertiliser rates than in non-fertilised control. Half and full fertiliser rates increased tomato yield by $37 \%$ and $61 \%$ in the first crop and by $21 \%$ and $32 \%$ in the second crop, respectively, mainly due to a significantly higher number of clusters per plant. There was no significant difference in average fruit weight when compared to control.

Plants inoculated with the mycorrhizal formulation provided a significantly higher yield compared to the non-inoculated plants, mainly due to a higher number of clusters and fruit.

All yield parameters showed a statistically significant interaction only between crop cycle and mineral fertilisation.

The second tomato crop was earlier than the first, providing a $34.9 \%$ larger yield (+) in a 14-day shorter MHT (Table 4).

Both mineral fertilisation and mycorrhizal inoculation also resulted in a significantly earlier crop harvest than the non-treated control, increasing first harvest yield by $4.6 \%$ and $4.1 \%$ in a 3.5 - and 2-day shorter MHT, respectively.

Tomato fruit dry matter and soluble solids content were significantly higher in the second than in the first crop, without any significant influence of either mineral fertilisation or mycorrhizal inoculation.

\section{Mycorrhization parameters}

At transplant, presence of fungal mycelium was clearly evident on tomato seedling roots previously inoculated with the mycorrhizal formulation, whereas almost no endomycorrhizal structures were observed in non-inoculated plants (Table 4).

There was only a slight variation in frequency of mycorrhization (F\%) and arbuscule presence (a\%) between the two crops (Table 5). Mycorrhization frequency and arbuscule presence at half cycle were significantly higher in the second than in the first crop. In contrast, mycorrhization indices at the end of the crop were significantly higher in the first than in the second year.

No significant interaction was found between mineral fertilisation and mycorrhization, although at the end of the crop almost all mycor-

Table 2. Effects of fertilization and mycorrhization on plant growth parameters and occurrence of phenological phases at mid crop cycle.

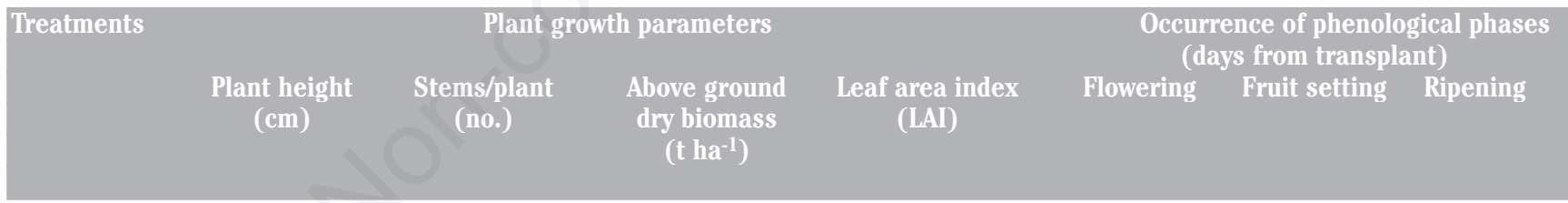

\begin{tabular}{|c|c|c|c|c|c|c|c|}
\hline \multicolumn{8}{|l|}{ Years (Y) } \\
\hline 2006 & $54.7^{\mathrm{b}}$ & $7.2^{\mathrm{a}}$ & $1.5^{b}$ & $0.9^{\mathrm{b}}$ & $32.4^{\mathrm{a}}$ & $45.1^{\mathrm{a}}$ & $64.8^{\mathrm{a}}$ \\
\hline 2007 & $74.9^{\mathrm{a}}$ & $6.5^{b}$ & $3.8^{\mathrm{a}}$ & $3.0^{\mathrm{a}}$ & $23.6^{\mathrm{b}}$ & $36.8^{b}$ & $58.5^{\mathrm{b}}$ \\
\hline Significance & $* *$ & $* *$ & $* *$ & $* *$ & $* *$ & $* *$ & $* *$ \\
\hline \multicolumn{8}{|l|}{ Fertilization (F) } \\
\hline 0 & $57.1^{\mathrm{c}}$ & $6.4^{c}$ & $1.8^{\mathrm{c}}$ & $1.2^{\mathrm{c}}$ & $29.2^{\mathrm{a}}$ & $41.9^{\mathrm{a}}$ & $62.3^{\mathrm{a}}$ \\
\hline 50 & $65.1^{\mathrm{b}}$ & $6.9^{b}$ & $2.8^{b}$ & $2.0^{\mathrm{b}}$ & $27.6^{\mathrm{b}}$ & $40.6^{\mathrm{b}}$ & $61.3^{\mathrm{a}}$ \\
\hline 100 & $72.2^{\mathrm{a}}$ & $7.2^{\mathrm{a}}$ & $3.3^{\mathrm{a}}$ & $2.7^{\mathrm{a}}$ & $27.3^{b}$ & $40.3^{b}$ & $61.3^{\mathrm{a}}$ \\
\hline Significance & $* *$ & $* *$ & $* *$ & $* *$ & $* *$ & $* *$ & ns \\
\hline \multicolumn{8}{|c|}{ Mycorrhization (M) } \\
\hline Micosat F. & $66.2^{\mathrm{a}}$ & $7.2^{\mathrm{a}}$ & $2.9^{\mathrm{a}}$ & $2.2^{\mathrm{a}}$ & $27.1^{\mathrm{b}}$ & $40.4^{\mathrm{b}}$ & $61.4^{\mathrm{a}}$ \\
\hline Control & $63.4^{\mathrm{b}}$ & $6.5^{b}$ & $2.3^{b}$ & $1.8^{\mathrm{b}}$ & $29.0^{\mathrm{a}}$ & $41.5^{\mathrm{a}}$ & $61.9^{\mathrm{a}}$ \\
\hline Significance & $*$ & $* *$ & $* *$ & $* *$ & $* *$ & $* *$ & ns \\
\hline \multicolumn{8}{|l|}{ Interactions } \\
\hline $\mathrm{YxF}$ & ns & ns & ns & $* *$ & $*$ & $* *$ & ns \\
\hline YxM & ns & ns & ns & ns & ns & ns & ns \\
\hline $\mathrm{F} \times \mathrm{M}$ & ns & ns & ns & ns & ns & ns & ns \\
\hline YxFxM & ns & ns & ns & ns & ns & ns & ns \\
\hline
\end{tabular}

a,b,c Means followed by the same letters in the same column and within each experiment are not significantly ( $\alpha \leq 0.05)$ different according to the Student-Newman-Keuls Test. *P $\leq 0.05$ was considered significant; ${ }^{* *} \mathrm{P} \leq 0.01$. ns, non-significant. 
Table 3. Effects of fertilisation and mycorrhization on tomato yield, fruit quality, crop earliness and plant growth at harvest.

\begin{tabular}{|c|c|c|c|c|c|c|c|c|c|c|c|c|}
\hline \multirow[t]{2}{*}{ Treatments } & \multicolumn{2}{|c|}{ Yield } & \multirow{2}{*}{$\begin{array}{c}\text { Clusters per } \\
\text { plant (N) }\end{array}$} & \multicolumn{3}{|c|}{ Fruit quality } & \multicolumn{3}{|c|}{ Crop earliness } & \multicolumn{3}{|c|}{ Plant growth } \\
\hline & $\begin{array}{c}\text { Total } \\
(\mathrm{t} \mathrm{ha-1})\end{array}$ & $\begin{array}{c}\text { Marketable } \\
\left(\mathrm{t} \mathrm{ha}^{-1}\right)\end{array}$ & & $\begin{array}{c}\text { N/ } \\
\text { plant }\end{array}$ & $\begin{array}{l}\text { Mean } \\
\text { weight } \\
\text { (g) }\end{array}$ & $\begin{array}{l}\text { Soluble } \\
\text { solids } \\
\left({ }^{\circ} \text { Brix) }\right.\end{array}$ & $\begin{array}{c}\text { Dry } \\
\text { matter } \\
(\%)\end{array}$ & $\begin{array}{l}\text { Yield at } 1^{\text {st }} \\
\text { harvest } \\
(\%)\end{array}$ & $\begin{array}{l}\text { Harvest } \\
\text { mean } \\
\text { time (d) }\end{array}$ & $\begin{array}{l}\text { Above ground } \\
\text { dry biomass } \\
\left(\mathrm{t} \mathrm{ha}^{-1}\right)\end{array}$ & $\begin{array}{c}\text { Harvest } \\
\text { index }\end{array}$ & Stems (no.) \\
\hline
\end{tabular}

Years (Y)

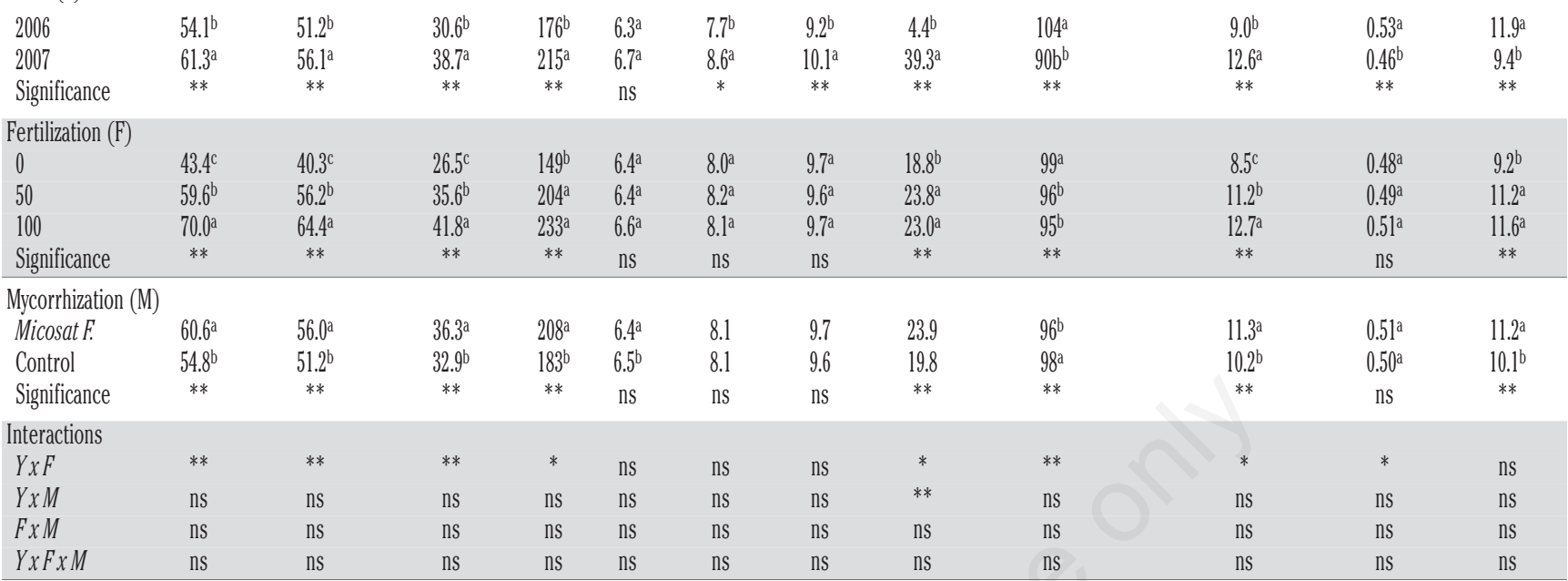

a.b,çMeans followed by the same letters in the same column and within each experiment are not significantly $(\alpha \leq 0.05)$ different according to the Student-Newman-Keuls Test. *P $\leq 0.05$ was considered significant; **P $\leq 0.01$. ns, non-significant.

Table 4. Mycorrhization parameters of tomato seedling roots at transplant.

\begin{tabular}{|c|c|c|c|c|c|c|c|c|c|c|}
\hline \multirow[t]{2}{*}{ Mycorrhizal treatments } & \multirow{2}{*}{\multicolumn{2}{|c|}{$\mathrm{F} \%$}} & \multicolumn{6}{|c|}{ Mycorrhizal indices } & \multirow{2}{*}{\multicolumn{2}{|c|}{$\mathbf{A} \%$}} \\
\hline & & & 2006 & 2007 & & & & 2007 & & \\
\hline Control & $5.6^{\mathrm{b}}$ & $6.7^{\mathrm{b}}$ & $0.1^{\mathrm{b}}$ & $0.1^{\mathrm{b}}$ & $1.0^{\mathrm{b}}$ & $1.0^{\mathrm{b}}$ & $0.0^{\mathrm{b}}$ & $5.0^{\mathrm{b}}$ & $0.0^{\mathrm{b}}$ & $0.0^{\mathrm{b}}$ \\
\hline Micosat F. & $100.0^{\mathrm{a}}$ & $100.0^{\mathrm{a}}$ & $5.1^{\mathrm{a}}$ & $5.5^{\mathrm{a}}$ & $5.1^{\mathrm{a}}$ & $5.5^{\mathrm{a}}$ & $24.3^{\mathrm{a}}$ & $9.4^{\mathrm{a}}$ & $1.3^{\mathrm{a}}$ & $0.6^{\mathrm{a}}$ \\
\hline Significance & $* *$ & $* *$ & $* *$ & $* *$ & $* *$ & $* *$ & $* *$ & $* *$ & $* *$ & $* *$ \\
\hline
\end{tabular}

$a, b$ Means followed by the same letters in the same column and within each experiment are not significantly $(\alpha \leq 0.05)$ different according to the Student-Newman-Keuls Test; **P $\leq 0.01$ was considered significant. ns, non-significant.

Table 5. Mycorrhization parameters on tomato roots at mid (flowering-fruit setting stage) and end crop cycle.

\begin{tabular}{|c|c|c|c|c|c|c|c|c|c|c|}
\hline \multirow[t]{2}{*}{ Treatments } & \multicolumn{10}{|c|}{ Mycorrhizal indices } \\
\hline & Mid & End & Mid & End & Mid & End & Mid & End & Mid & End \\
\hline \multicolumn{11}{|l|}{ Years (Y) } \\
\hline 2006 & $67.4^{b}$ & $77.0^{\mathrm{a}}$ & $17.1^{\mathrm{a}}$ & $26.2^{\mathrm{a}}$ & $17.7^{\mathrm{a}}$ & $27.2^{\mathrm{a}}$ & $40.3^{b}$ & $35.5^{\mathrm{a}}$ & $12.2^{\mathrm{a}}$ & $14.8^{\mathrm{a}}$ \\
\hline 2007 & $69.6^{\mathrm{a}}$ & $61.9^{b}$ & $19.3^{\mathrm{a}}$ & $25.2^{\mathrm{a}}$ & $20.4^{\mathrm{a}}$ & $25.8^{\mathrm{a}}$ & $50.5^{\mathrm{a}}$ & $27.8^{\mathrm{b}}$ & $14.1^{\mathrm{a}}$ & $13.7^{\mathrm{a}}$ \\
\hline Significance & $*$ & $* *$ & ns & ns & ns & ns & $* *$ & $* *$ & ns & ns \\
\hline \multicolumn{11}{|c|}{ Fertilization (F) } \\
\hline 0 & $66.4^{\mathrm{b}}$ & 67.8 & $9.9^{\mathrm{b}}$ & $23.3^{b}$ & $10.5^{b}$ & $23.3^{\mathrm{b}}$ & $47.2^{\mathrm{a}}$ & $27.4^{\mathrm{b}}$ & $8.1^{\mathrm{b}}$ & $11.8^{\mathrm{b}}$ \\
\hline 50 & $67.8^{\mathrm{ab}}$ & 70.0 & $24.0^{\mathrm{a}}$ & $23.3^{b}$ & $24.5^{\mathrm{a}}$ & $23.9^{b}$ & $37.1^{\mathrm{b}}$ & $27.0^{\mathrm{b}}$ & $15.8^{\mathrm{a}}$ & $9.9^{b}$ \\
\hline 100 & $71.4^{\mathrm{a}}$ & 70.5 & $20.7^{\mathrm{a}}$ & $30.5^{\mathrm{a}}$ & $22.1^{\mathrm{a}}$ & $32.2^{\mathrm{a}}$ & $51.8^{\mathrm{a}}$ & $40.6^{\mathrm{a}}$ & $15.5^{\mathrm{a}}$ & $20.9^{\mathrm{a}}$ \\
\hline Significance & $* *$ & ns & $* *$ & $* *$ & $* *$ & $* *$ & $* *$ & $* *$ & $* *$ & $* *$ \\
\hline \multicolumn{11}{|c|}{ Mycorrhization (M) } \\
\hline Micosat F. & 100.0 & 99.4 & 35.2 & 49.7 & 35.2 & 50.0 & 76.1 & 55.1 & 25.8 & 28.2 \\
\hline Control & 37.0 & 39.4 & 1.2 & 1.6 & 2.9 & 3.0 & 14.7 & 8.3 & 0.5 & 0.2 \\
\hline Significance & $* *$ & $* *$ & $* *$ & $* *$ & $* *$ & $* *$ & $* *$ & $* *$ & $* *$ & $* *$ \\
\hline \multicolumn{11}{|l|}{ Interactions } \\
\hline$A x C$ & * & ns & ns & ns & ns & $*$ & ns & $*$ & ns & $* *$ \\
\hline$A \times M$ & ns & $* *$ & ns & ns & ns & ns & $*$ & ns & ns & ns \\
\hline$C x M$ & $* *$ & $\mathrm{~ns}$ & $* *$ & $* *$ & $* *$ & $*$ & $* *$ & $* *$ & $* *$ & $* *$ \\
\hline$A \times C \times M$ & $*$ & $\mathrm{~ns}$ & ns & $* *$ & ns & $* *$ & $*$ & $* *$ & ns & $* *$ \\
\hline
\end{tabular}

${ }_{a, b}$ Means followed by the same letters in the same column and within each experiment are not significantly $(\alpha \leq 0.05)$ different according to the Student-Newman-Keuls Test. **P $\leq 0.01$ was considered significant. ns, non-significant. 
rhization indices were significantly higher in the fully fertilised plots than in non-fertilised soil.

\section{Discussion and conclusions}

Tomato yield performance was affected in different ways by climatic conditions in the two years studied. High temperatures were recorded in the last ten days of June 2006, and these induced anthoptosis and almost completely prevented fruit setting in the first crop.

Low mycorrhization indices of non-inoculated plants demonstrated that natural symbiosis with soil-native AMF populations is of little benefit to conventional tomato crops, particularly in the climatic conditions recorded during this experiment.

Artificial AMF inoculation was shown to be highly and rapidly effective on plant growth. Inoculated tomato seedlings were significantly larger than non-inoculated seedlings after less than 30 days after the first inoculation in the nursery, and dry top biomass and stem number of inoculated plants were found to be higher also at the end of each crop. The positive effects of mycorrhizal inoculation were extended also to marketable yield of both crops, mainly as a result of an increased number and weight of clusters and fruits. The improvement in tomato plant growth and yield through AMF inoculation has already been reported for tomato (Salvioli et al., 2012) and for other different vegetable species (Douds et al., 2007; Regvar et al., 2003). In field conditions, tomato plants inoculated with a commercial formulation of Glomus intraradices were recently found to produce larger inflorescences, and a higher number of flowers and total and marketable fruits (Conversa et al., 2012). In contrast, the same commercial mycorrhizal formulate tested in our experiment did not result in any significant increase in either total or marketable yield of an organic tomato crop, probably due to a natural organic soil richness (Bosco et al., 2007).

The higher efficiency of mycorrhizal plants in taking up soil phosphate, and thus improving plant nutritional status, was suggested to be one reason for the positive impact of AMF mycorrhization on tomato plant productivity (Subramanian et al., 2006). It was also hypothesised that enhanced fruit setup and yield could also be related to an increase in pollen quantity and quality in mycorrhizal plants (Poulton et al., 2001; Subramanian et al., 2006).

Mycorrhizal treatment also improved crop earliness, seen as accelerating plant flowering, an increase in first harvest yield and a reduction in the average harvesting time compared to non-inoculated plants.

Accelerated flowering and a faster fruit production following tomato plant inoculation with the AM fungi $G$. mossae or $G$. intraradices have previously been reported by Salvioli et al. (2012) and Hildebrandt et al. (2002), respectively. Salvioli et al. (2012) also hypothesised that accelerated flowering could also be due to a forced meristem transition from the vegetative to floral status or to the effects of mycorrhizal fungus on the expression of flowering-related genes.

In our experiment, quality parameters of tomato fruit were not significantly affected by plant AMF inoculation. This is in contrast to many other studies documenting a positive impact of root inoculation with beneficial rhizosphere microorganisms on fruit quality parameters (Charron et al., 2001; Kaya et al., 2003; Mena-Violante et al., 2006). An increase in antioxidant activity and a higher lycopene and shoot and fruit potassium content were also reported for tomato fruits from AMFinoculated plants (Ordookhani et al., 2010).

Plant-growth-promoting fungi inoculation was generally found to increase plant nutrient uptake, due to a better water and nutrient absorption by the improved root system (Höflich and Kühn, 1996; Kloepper et al., 1991; Zimmer et al., 1995). Combination of AMF with PGPR was generally found to result in a synergistic positive interaction
(Galleguillos et al., 2000; Hameeda et al., 2007), although neutral effects were also observed in other studies (Andrade et al., 1997; Walley and Germida, 1997).

In our study, mineral fertilisation had a positive effect on plant growth and marketable yield and accelerated crop flowering, fruit veraison and harvesting time, but did not influence fruit quality parameters. No significant interaction was found between mineral fertilisation and plant mycorrhization, although the few variations in mycorrhization frequency and arbuscule presence in the two tomato crops were more evident when the full quantity of full fertiliser was given. Mineral fertilisation was usually reported to decrease AMF colonisation in agricultural crops, as a lower AMF activity was observed in conventional agricultural systems with high inputs of inorganic fertilisers than in organic crop systems (Douds et al., 1993). However, use of fertiliser in extremely nutrient deficient soils was found to increase AMF colonisation (Hayman, 1975), to mycorrhizal function. (Gryndler et al., 1990). Based on these contrasting responses, the mediation of plant nutritional status in the mycorrhizal response to fertilisers was suggested by Douds and Johnson (2003). In particular, P:N ratio seems to be an important factor governing AMF response to nutrient enrichment, as AMF colonisation was generally found to be reduced by $\mathrm{P}$ fertilisation in the presence of adequate $\mathrm{N}$ levels, but not necessarily in $\mathrm{N}$-limited plants (Sylvia and Neal, 1990).

Inoculation of tomato plants with AMF, both alone or in combination with PGPR, can provide considerable benefits in terms of growth, nutrient uptake and also yield, although results are difficult to predict and are not always guaranteed. More generally, application of mycorrhizal formulations in intensive tomato systems may improve crop sustainability, due to a reduced impact of fertilisers and pesticides. However, the large variability of plant response to mycorrhization between crops and within crop varieties suggests that it would be useful to extend research to a wider range of tomato genotypes studied over a longer period of time.

\section{References}

Allen MF, 2009. Water relations in the mycorrhizosphere. Progr. Bot. 257-76.

Andrade G, Mihara KL, Linderman RG, Bethlenfalvay GJ, 1997. Bacteria from rhizosphere and hyphosphere soils of different arbuscularmycorrhizal fungi. Plant Soil 192:71-9.

Avis TJ, Gravel V, Antoun, H, Tweddell RJ, 2008. Multifaceted beneficial effects of rhizosphere microorganisms on plant health and productivity. Soil Biol. Biochem. 40:1733-40.

Bosco M, Giovannetti G, Picard C, Baruffa E, Brondolo A, Sabbioni F, 2007. Commercial plant-probiotic microorganisms for sustainable organic tomato production systems. pp 468-471 in Proc. 3rd QLIF Congress, Hohenheim, Germany.

Brundrett MC, 2009. Mycorrhizal associations and other means of nutrition of vascular plants: understanding the global diversity of host plants by resolving conflicting information and developing reliable means of diagnosis. Plant Soil 320:37-77.

Burrows RL, Pfleger FL, 2002. Host responses to AMF from plots differing in plant diversity. Plant Soil 240:169-80.

Charron G, Furlan V, Bernier-Cardou M, Doyon G, 2001. Response of onion plants to arbuscular mycorrhizae. Mycorrhiza 11:187-97.

Compant S, Duffy B, Nowak J, Clément C, Barka EA, 2005. Use of plant growth-promoting bacteria for biocontrol of plant diseases: principles, mechanisms of action, and future prospects. Appl. Environ. Microbiol. 71:4951-9.

Conversa G, Lazzizera, C, Bonasia A, Elia A, 2012. Yield and phospho- 
rus uptake of a processing tomato crop grown at different phosphorus levels in a calcareous soil as affected by mycorrhizal inoculation under field conditions. Biol. Fertil. Soil 49:1-13.

Daniell TJ, Husband R, Fitter A H, Young JPW, 2001. Molecular diversity of arbuscular mycorrhizal fungi colonising arable crops. FEMS Microbiol. Ecol. 36:203-9.

Douds DD Jr, Johnson NC, 2003. Contributions of arbuscular mycorrhizas to soil biological fertility. In: L.K. Abbott and D.V. Murphy (eds), Soil biological fertility - a key to sustainable land use in agriculture). Kluwer Academic Publishers, Dordrecht, the Netherlands, pp 129-62.

Douds DD Jr, Janke RR, Peters SE, 1993. VAM fungus spore populations and colonization of roots of maize and soybean under conventional and low-input sustainable agriculture. Agric. Ecosyst. Environ. 43:325-35.

Douds DD Jr, Nagahashi G, Reider C, Hepperly P, 2007. Inoculation with am fungi increases the yield of potatoes in a high P soil. Biol. Agric. Hortic. 25:67-78.

Galleguillos C, Aguirre C, Miguel Barea J, Azcón R, 2000. Growth promoting effect of two Sinorhizobium melilotistrains (a wild type and its genetically modified derivative) on a non-legume plant species in specific interaction with two arbuscular mycorrhizal fungi. Plant Sci. 159:57-63.

Gosling P, Hodge A, Goodlass G, Bending GD, 2006. Arbuscular mycorrhizal fungi and organic farming. Agric. Ecosyst. Environ. 113:1735 .

Gryndler M, Leština J, Moravec V, P ikryl Z, Lipavský J, 1990. Colonization of maize roots by VAM-fungi under conditions of longterm fertilization of varying intensity. Agric. Ecosyst. Environ. 29:183-6.

Hameeda B, Srijana M, Rupela OP, Reddy G, 2007. Effect of bacteria isolated from composts and macrofauna on sorghum growth and mycorrhizal colonization. World J. Microbiol. Biotechnol. 23:883-7.

Hamel C, Plenchette C, 2007. Mycorrhizae in crop production. Haworth Food \& Agricultural Products Press, Binghamton, NY, USA.

Hayman DS, 1975. The occurrence of mycorrhiza in crops as affected by soil fertility. Endomycorrhizas. Academic Press, London, UK, pp 495-509.

Hildebrandt U, Schmelzer E, Bothe H, 2002. Expression of nitrate transporter genes in tomato colonized by an arbuscular mycorrhizal fungus. Physiol. Plantarum 115:125-36.

Hodge A, Campbell CD, Fitter AH, 2001. An arbuscular mycorrhizal fungus accelerates decomposition and acquires nitrogen directly from organic material. Nature 413: 297-9.

Höflich G, Kühn G, 1996. Förderung des Wachstums und der Nährstoffaufnahme bei kruziferen Ölund Zwischenfrüchten durch inokulierte Rhizosphärenmikroorganismen. Zeitschr. Pflanzenernähr. Bodenk. 159:575-81.

Jeffries P, Gianinazzi S, Perotto S, Turnau K, Barea JM, 2003. The contribution of arbuscular mycorrhizal fungi in sustainable maintenance of plant health and soil fertility. Biol. Fertil. Soils. 37:1-16.

Kahiluoto H, Ketoja E, Vestberg M, Saarela I, 2001. Promotion of AM utilization through reduced $\mathrm{P}$ fertilization 2. Field studies. Plant Soil 231:65-79.

Kaya C, Higgs D, Kirnak H, Tas I, 2003. Mycorrhizal colonisation improves fruit yield and water use efficiency in watermelon (Citrullus lanatus Thunb.) grown under well-watered and waterstressed conditions. Plant Soil 253:287-92.

Kloepper JW, Zablotowick RM, Tipping EM, Lifshitz R, 1991. Plant growth promotion mediated by bacterial rhizosphere colonizers. In: D.L. Keister, P.B. Cregan (eds.) The rhizosphere and plant growth.
Kluwer Academic Publishers Dordrecht, The Netherlands, pp 315-26. Kogelmann WJ, Lin HS, Bryant RB, Beegle DB, Wolf AM, Petersen GW, 2004. A statewide assessment of the impacts of phosphorus-index implementation in Pennsylvania. J. Soil Water Conserv. 59:9-18.

Larsen J, Ravnskov S, Sorensen JN, 2007. Capturing the benefits of arbuscular mycorrhizae in horticulture. In: C. Hamel and C. Plenchette (eds), Mycorrhizae in crop production. The Haworth Press Inc., New York, USA, pp 123-49.

Mäder P, Fliessbach A, Dubois D, Gunst L, Fried P, Niggli U, 2002. Soil fertility and biodiversity in organic farming. Science 296:1694-7.

Mena-Violante HG, Ocampo-Jiménez 0, Dendooven L, Martínez-Soto G, González-Castañeda J, Davies Jr FT, Olalde-Portugal V, 2006. Arbuscular mycorrhizal fungi enhance fruit growth and quality of chile ancho (Capsicum annuum L. cv San Luis) plants exposed to drought. Mycorrhiza 16:261-7.

Ordookhani K, Khavazi K, Moezzi A, Rejali F, 2010. Influence of PGPR and AMF on antioxidant activity, lycopene and potassium contents in tomato. Afr. J. Agric. Res. 5:1108-16.

Poulton JL, Koide RT, Stephenson AG, 2001. Effects of mycorrhizal infection, soil phosphorus availability and fruit production on the male function in two cultivars of Lycopersicon esculentum. Plant Cell Environ. 24:841-9.

Regvar M, Vogel-Mikuš K, Ševerkar T, 2003. Effect of AMF inoculum from field isolates on the yield of green pepper, parsley, carrot, and tomato. Folia Geobot. 38:223-34.

Salvioli A, Zouari I, Chalot M, Bonfante P, 2012. The arbuscular mycorrhizal status has an impact on the transcriptome profile and amino acid composition of tomato fruit. BMC Plant Biol. 12:44.

Smith SE, Read DJ, 2008. (eds.) Mycorrhizal symbiosis, 3rd ed. Academic Press, Elsevier, Amsterdam, The Netherlands.

Subramanian KS, Santhanakrishnan P, Balasubramanian P, 2006. Responses of field grown tomato plants to arbuscular mycorrhizal fungal colonization under varying intensities of drought stress. Sci. Hortic. 107:245-53.

Sylvia DM, Neal LH, 1990. Nitrogen affects the phosphorus response of VA mycorrhiza. New Phytol. 115:303-10.

Tilman D, Cassman KG, Matson PA, Naylor R, Polasky S, 2002. Agricultural sustainability and intensive production practices. Nature 418:671-7.

Treseder KK, Allen MF, 2002. Direct nitrogen and phosphorus limitation of arbuscular mycorrhizal fungi: a model and field test. New Phytol. 155:507-15.

Trouvelot A, Kough JL, Gianinazzi-Pearson V, 1986. Estimation of VA mycorrhizal infection levels. Research for methods having a functional significance. pp 217-221 in Proc. 1st European symposium, Physiological and genetical aspects of mycorrhizae, Dijon. Centre National de la Recherche Scientifique, Dijon; Institut National de la Recherche Agronomique, Dijon; Station d'Amelioration des Plantes, Paris, France.

Walley FL, Germida JJ, 1997. Response of spring wheat (Triticum aestivum) to interactions between Pseudomonas species and Glomus clarum NT4. Biol. Fertil. Soils 24:365-71.

Wissuwa M, Mazzola M, Picard C, 2009. Novel approaches in plant breeding for rhizosphere-related traits. Plant Soil 321:409-30.

van der Heijden MG, Klironomos JN, Ursic M, Moutoglis P, StreitwolfEngel R, Boller T Sanders I R, 1998. Mycorrhizal fungal diversity determines plant biodiversity, ecosystem variability and productivity. Nature 396:69-72.

Zimmer W, Kloss K, Hundeshagen B, Niederau E, 1995. Auxin biosynthesis and denitrification in plant growth promoting bacteria. NATO ASI Ser. G Ecol. Sci. 37:121. 